\title{
Analysis of the oil market and the impact of integration processes on socio-economic development indicators of Russia
}

\author{
Guzaliya Klychova $^{1}$, Alsou Zakirova ${ }^{1, *}$, Movlatkhan Shadieva ${ }^{2}$, Ullah Raheem ${ }^{3}$, and Ayaz \\ Zakirov $^{3}$ \\ ${ }^{1}$ Kazan State Agrarian University, 65, Karl Marx str., 420015, Kazan, Russia \\ ${ }^{2}$ Ingush State University, 7, Zyazikova M.B. str., 386001, Magas, Russia \\ ${ }^{3}$ Kazan (Volga) Federal University, 18, Kremlevskaya str., 420008, Kazan, Russia
}

\begin{abstract}
In modern conditions oil and gas sector is not only the largest sector of the economy, also this industry plays an important role in social and economic development of the state. In this regard, there is a need for effective regulation of the oil and gas complex, in particular, the state regulation. Market concentration indices CR-3, CR-4, HerfindahlHirschman index, Hall-Teidman index and Lind index have been calculated for competitive environment analysis. Having analyzed the competitive environment of the Russian oil market in 2015-2019, it was possible to find out that the Russian oil market in 2015-2016 was moderately concentrated, in 2017-2019 - highly concentrated; during the whole period under consideration the Russian oil market was a monopolistic competition market. The study also analyzed the impact of integration processes on the indicators of socio-economic development of the country. The analysis revealed that gross domestic product (GDP) and consolidated budget revenues are moderately strongly influenced by integration processes on the oil market; the volume of oil production with gas condensate is moderately influenced by them. At the same time, integration processes in the oil market do not have a significant impact on economic growth and foreign trade balance.
\end{abstract}

\section{Introduction}

In the industrial structure of the Russian Federation, more than $30 \%$ of industrial production is natural production industry. Currently, the largest and most stable production base in the Russian economy The natural business industry is the oil and gas sector, which is part of the national fuel and energy complex. 16 Therefore, as of January 1, 2020. 292 organizations with underground soil use legal licenses are producing oil and gas condensate reservoirs of(petroleum and raw material) in the territory of the Russian Federation. Including:

1) 105 organizations included in the structure of 11 giant companies (VINC), so that is stated to the year results, accounted for a total of $84.7 \%$ of all national oil production;

\footnotetext{
*Corresponding author: zakirovaar@mail.ru
} 
2) 184 independent production companies which are not part of vertically integrated companies VINC;

3) so 3 companies functioning under production joint sales.

According to the results of 2019, the volume of national crude oil production increased by $5.2 \mathrm{mln}$ tons compared to 2018 . (+0.9\%) and amounted to $561.2 \mathrm{mln}$ tons in absolute terms.

It is worth mentioning that today it is the vertically integrated oil companies (VINC) that have the decisive role in the Russian oil industry. They are responsible for $90 \%$ of oil production and refining, supplying petroleum products to end consumers. VINC are large energy companies which have subsidiaries in their structure and have direct influence on oil refineries. At the same time the subsidiaries are practically independent organizations with their own management center, resource base, etc.

The oil and gas sector is not only the biggest sector, but also plays an important role in the socio-economic development of the state, employing more than two million people. Moreover, the oil and gas sector is still the main source of foreign currency and tax revenues of the country. At the same time, it accounts for about 12 percent of the total industrial production. This is due to the fact that the oil industry is the largest taxpayer in the Russian Federation.

Thus, due to the importance and dependence of certain social and economic indicators on the results of the oil and gas complex, there is a need for its effective regulation, in particular, state regulation.

National institutions adopt, implement and control the implementation of regulatory actions, adopting specific methods, forms and tools that have an impact on the business structure. Therefore, the economic supervision of the country (including the oil and natural gas complex) has been found. In this process, the drawbacks of the market mechanism have been eliminated and alleviated, and the source of ensuring the sustainable development of the economy has been found.

The state's method of economic regulation is a series of influence methods of the state on economic entities. The purpose is to improve the efficiency of its financial and economic activities and create conditions for the stable development of various sectors of the national economy.

The state affects the activities of economic subjects through the legislative and executive bodies of state power with active and passive, direct and indirect, legal, administrative and economic methods.

State bodies, using active methods, promptly regulate the permanently changing economic situation in the country and beyond its borders, taking into account factors of external and internal environment. One of the active methods of state regulation is determining the refinancing rate by the Central Bank of Russia.

Passive methods are measures to create compulsory or recommendatory norms, which must be met by economic subjects, implementing the strategic objectives of development and at the same time respecting the interests of society. For example, the state adopts appropriate legislative acts and monitors their implementation.

Direct state regulation is aimed at specific economic subjects and is associated with the implementation of state orders and contracts; targeted financing of certain sectors of the economy, territories and enterprises; targeted preferential lending to producers; cofinancing of construction of state property; licensing of certain activities.

Indirect methods imply influence on economic interests of economic entities by means of commodity-monetary levers of influence. Among the most important indirect methods are: forecasting the activities of enterprises aimed at economic development and implementation of investment projects; optimization of the tax system; regulation of the policy in the sphere of pricing, insurance and banking spheres. 
Legal methods are based on legislative norms regulating the financial and economic activity of the enterprise, relations of the enterprise with counteragents, defining the rights and forms of ownership of the economic subject.

Administrative methods - a set of methods by which the state affects the business processes and which are associated with the formation of a legal basis for the functioning of economic entities. Administrative methods ensure the stability of legal support of financial and economic activities of enterprises, the creation of a competitive environment. Administrative measures include pricing, licensing, quotas, state control of revenues, prices, credit rates, environmental conditions.

Economic methods are represented by budgetary and fiscal policy, monetary policy, planning, state target management. These methods influence nature of market relations, concentration of capital.

State regulation of the oil and gas complex is a mechanism including planning, regulation, control and correction of oil and gas enterprises activity with application of a set of legal, administrative and economic methods.

In Figure 1 it shows the national regulatory technique for the oil and gas industry in the economy. During the state adjustment process of the oil and gas complex, the following operations will be performed:

- manage activities in the fields of protection and utilization of underground soil, waste mining and utilization, mineral resources, and groundwater $[1,2]$,

- management of the package of shares of the oil and gas enterprises owned by the state $[3,4]$;

- ecological and geological control over the safe conduct of works, rational use of oil and gas $[5,6]$;

- tax, credit and pricing policies [7-10];

- licensing of activities;

- antimonopoly regulation [11].

The tasks of the state regulation of the oil and gas complex are:

- create world-class companies in the main sectors of the oil and gas sector of the economy;

- control the implementation of key decisions of oil and gas companies, including investment decisions regarding the establishment of production facilities [12];

- ensure the country's energy security [13-15];

- ensure the conditions for the development of scientific and technological progress in the oil and gas sector;

- enhancing the related evaluated standard legal regulation in the oil and gas sector of the economy;

- creation of effective transport and logistics system [16, 17];

- control of unreasonable overpricing of oil and gas products sold in the domestic market;

- regulation of monetary and credit relations, providing the enterprises of oil and gas complex with free financial resources;

- providing innovation and investment development of oil and gas companies;

- improvement of the tax and budget policy in order to develop the productive potential of the oil and gas sector enterprises.

The state regulation of the oil and gas sector of the economy assumes increase of social and economic indicators, improvement of investment attractiveness, improvement of quality and standard of living of the population of the Russian Federation. The scale of state regulation depends on the level of socio-economic development and geopolitical conditions [18]. 


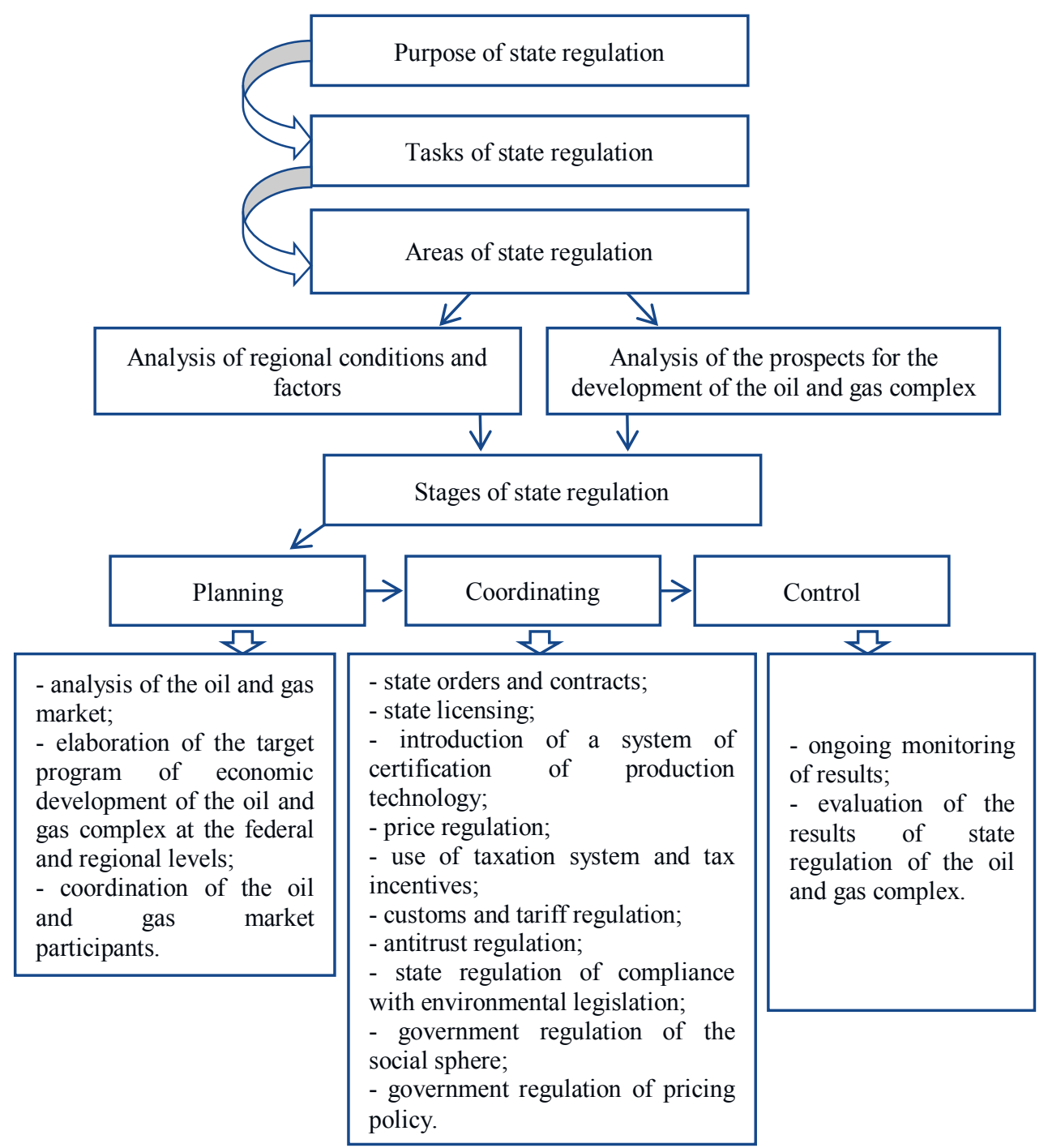

Fig. 1. Mechanism of state regulation of oil and gas complex of the Russian Federation.

The study of the theoretical foundations of the oil market analysis allowed us to identify the following stages of its implementation:

- study goods and services;

- to study supply and demand,

- study the behavior of actual and potential consumers;

- to study the market conjuncture;

- to study the dynamics of prices for the purpose of optimum product promotion in the market [19-22].

As an object of the analysis of branch markets it is accepted to allocate set of the companies which have common interests in one sector of economy, and represents an economic branch. The economic industry is represented by the production, distribution and consumption of a particular type of goods and services. 
With the help of methods of analysis all indicators and the market as a whole are studied in an integrated way.

The methods used in market research include: statistical data processing, multivariate methods, simulation methods, regression methods, correlation methods, statistical theory, hybrid methods, deterministic methods and other methods [23-27].

The choice of one or another method is influenced by the circumstances and goals of the analysis. And the objectivity of indicators is influenced by the combination of several methods.

The conjuncture of the raw materials market is understood as a specific economic situation on the market in a specific period of time.

In the study of the raw materials market the following activities are carried out:

- conjuncture information is collected and processed;

- Integral and differential assessment of the market is carried out:

- the scale of the market is characterized;

- market trends are detected, analyzed and forecasted;

- seasonality and cyclic pattern of market development are evaluated and analyzed

- assess and analyze regional differences in the market;

- evaluate and analyze business activities;

- assess business (market) risks;

- degree of monopoly and intensity of competition.

There are two stages of assessment of market conjuncture (fig. 2).

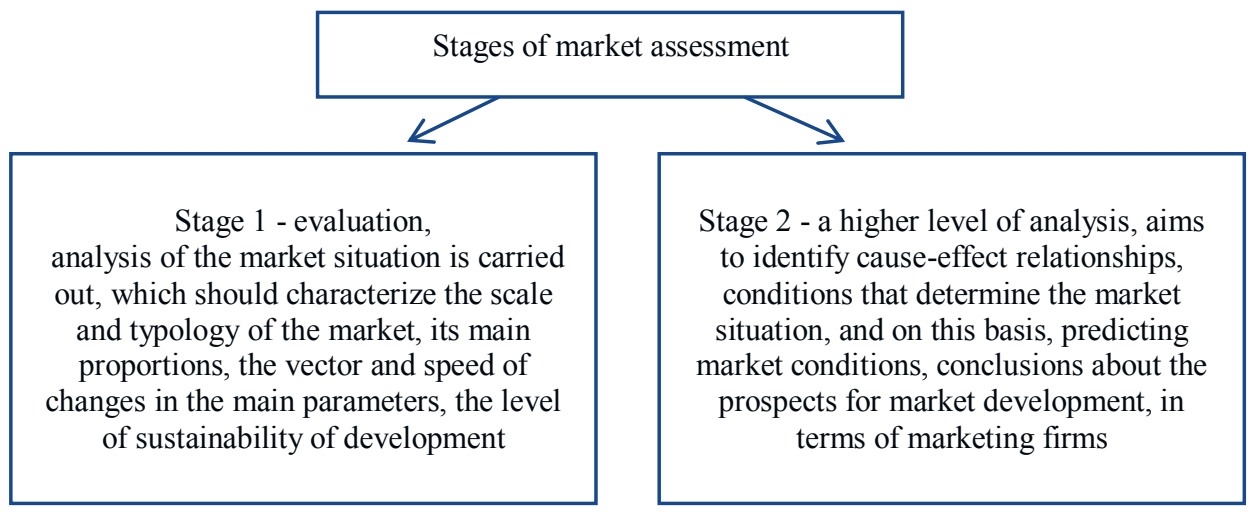

Fig. 2. The stages of assessing market conditions.

One of the key methods to assess the commodity markets' conjuncture is monitoring, which implies continuous observation of the element in order to assess its compliance with the desired result.

Monitoring of commodity markets involves the operation of the following systems:

1) an information base;

2) a complex of information processing methods (methodological base);

3) a complex of technical means of information registration, transmission and processing (technical base);

4) organizational structure, providing monitoring (organizational base).

In terms of time, monitoring is a continuous operation on collection and processing of information from various sources. It is always very time-consuming and expensive to conduct monitoring in full. Therefore, in economic practice, usually select individual parameters and sources of information, which are carefully monitored. 
The methodological basis of monitoring provides grouping and further processing of the information collected about the market. The processing of the collected and grouped data is carried.

\section{Materials and Methods}

To characterize the oil market in the Russian Federation, to analyze the competitive environment and economic concentration in this market we chose seven companies: PJSC Gazprom Neft, PJSC Lukoil, PJSC Rosneft Oil Company, PJSC Tatneft, PJSC NOVATEK, PJSC Surgutneftegaz, PJSC RussNeft (Fig. 3).

In order to determine the degree of economic concentration, it is necessary to analyze the competitive environment. When analyzing the competitive environment, assume the following steps are taken:

1) Determine the source of information;

2) Analyze the possibility of commodity exchangeability;

3) Define the industry and geographic area;

4) Identify major market participants;

5) Calculate qualitative and quantitative indicators of market concentration;

6) Draw conclusions about market competition conditions;

7) Developed recommendations to regulate the market. The following formula is used to analyze the competitive environment:

1) Market volume is the number of commodities that the market can absorb within a period of time under certain conditions.

Calculation of market volume:

$$
V_{m}=\sum_{i=1}^{n} V_{i}
$$

Calculation of the subject's market share:

$$
Q_{i}=\frac{V_{i}}{V_{m}} * 100 \%
$$

Where Vm - total sales volume (thousand rubles units); Vi - sales volume by the i-th seller; $\mathrm{n}$ - the number of sellers operating within the geographical boundaries of the market.

2) Index of market concentration CR-3, CR-4.

Calculation of market concentration indices:

$$
C R_{n}=\sum_{1}^{n} Q_{i}
$$

Where Qi - the share of sales of the i-th firm in the total market (in \%) by the seller of the product.

3) The Herfindahl-Hirschman index (HHI).

Calculation of the Herfindahl-Hirschman index:

$$
H H I=\sum_{i=1}^{n} Q_{i}^{2}
$$


Gazprom Neft is a vertically integrated oil company, whose main activities include oil and gas exploration and development, oil refining, as well as the production and sale of petroleum products. The structure of Gazprom Neft includes more than 70 oil producing, refining and marketing enterprises in Russia, CIS and non-CIS countries. The company refines around $80 \%$ of its crude oil production, achieving one of the best production/refining ratios in the Russian industry. In terms of refining volumes, "Gazprom Neft» is among the three largest companies in Russia, and ranks fourth in terms of production volumes.

PJSC NK «Rosneft Oil Company»
It is one of the largest vertically integrated oil \& gas companies in the world, accounting for more than $2 \%$ of global oil production and about $1 \%$ of proven hydrocarbon reserves. With a full production cycle, the Company has full control over the entire production chain - from oil and gas production to sales of petroleum products.

The leader of the Russian oil industry and the largest public oil and gas corporation in the world. The main activities of PJSC NK Rosneft are prospecting and exploration of hydrocarbon deposits, production of oil, gas, gas condensate, implementation of projects for the development of offshore fields, processing of extracted raw materials, sale of oil, gas and products of their processing in Russia and abroad.

It ranks fifth in Russia in terms of oil production. The Company is one of the largest Russian vertically integrated oil companies with dynamic development of oil and gas production, refining, oil and gas chemistry, tire complex, gas station network, electric power industry, development and manufacture of equipment for oil and gas industry and a block of service structures. "TATNEFT» also participates in the capital of financial sector companies. «Tatneft» is one of the largest Russian public companies with a market capitalization of more than US \$28 billion at the end of 2019 .

Russian gas company, as of the mid-2010s - the second largest natural gas producer in Russia in terms of production. PJSC «NOVATEK» is the largest independent natural gas producer in Russia. The company is engaged in the exploration, production, processing and marketing of natural gas and liquid hydrocarbons and has over twenty years of experience in the Russian oil and gas industry.

PJSC «Surgutneftegas» is one of the largest private vertically integrated oil companies in Russia, uniting in its structure research and development, geological exploration, drilling, production divisions, oil and gas processing, sales enterprises. PJSC «Surgutneftegas» is engaged in the processing of crude oil and associated petroleum gas, the processing of hydrocarbons for various types of petrochemical products, as well as the production of a wide range of petroleum products.

Russian oil company. «RussNeft» is the only major oil company in Russia created as a result of the consolidation of private assets on a purely market basis. The company was founded by the famous Russian

PJSC NK « RussNeft» businessman and public figure Mikhail Gutseriev with the financial support of the major Swiss trading company Glencore. The company has a diversified portfolio of assets in key oil and gas-bearing regions of Russia (the Volga-Ural region, Western and Central Siberia), as well as in Azerbaijan.

Fig. 3. Characteristics of the main companies of the oil and gas complex of Russia. 
The Herfindahl-Hirschman index is calculated taking into account data on all market participants. In contrast to $\mathrm{CR}$, it takes into account both the number of enterprises and their disparity in the market. The lower the value the index takes, the lower the concentration, the stronger the competition in this market and the weaker the market power of the firms, all other things being equal.

The Gerfindahl-Hirschman index allows us to divide all the markets into highly concentrated, moderately concentrated and low concentrated ones (Table 1).

Table 1. Numerical limits of CR-3, CR-4, HHI values for determining the level of market concentration.

\begin{tabular}{|c|c|c|}
\hline Highly concentrated & At $70 \%<\mathrm{CR} 3<100 \%$ & At $80 \%<\mathrm{CR} 4<100 \%$ \\
markets & $2000<\mathrm{HHI}<10000$ & $1800<\mathrm{HHI}<10000$ \\
\hline Moderately concentrated & At $45 \%<\mathrm{CR} 3<70 \%$ & At $45 \%<\mathrm{CR} 4<80 \%$ \\
markets & $1000<\mathrm{HHI}<2000$ & $1000<\mathrm{HHI}<1800$ \\
\hline \multirow{2}{*}{ Low Concentrated Markets } & At CR3 $<45 \%$ & At CR4 $<45 \%$ \\
& HHI $<1000$ & HHI $<1000$ \\
\hline
\end{tabular}

4) Hall-Teidman index (HT).

Calculation of the Hall-Teidman index:

$$
H T=\frac{1}{(-1)+2 \sum_{i=1}^{n} Q_{i} R_{i}}
$$

Where Qi - the share of sales of the i-th firm in the total market (in fractions); Ri- the rank of the $i$-th company in the market (in descending order, the largest company has a rank of 1). HT is always in the range from 0 to 1 .

Essentially similar to HHI, HT is calculated based on the comparison of the ranking of companies in the market with their market share. It is unique in that it can consider the company size ratio of the largest economic entity, so that a deeper analysis of the industry structure can be carried out. Therefore, the value of the Holtdeman Index allows us to determine the type of market competition. (Table 2).

Table 2. Numerical boundaries of HT values to determine the type of competition in the market.

\begin{tabular}{|c|l|}
\hline Numerical boundaries of HT & \multicolumn{1}{c|}{ The type of competition } \\
\hline 0 & Perfect Competition \\
\hline $0<\mathrm{HT}<0.3$ & The market is close to perfect competition \\
\hline $0.3 \leq \mathrm{HT}<0.5$ & Monopolistic Competition Market \\
\hline $0.5 \leq \mathrm{HT}<0.7$ & Oligopoly market \\
\hline $0.7 \leq \mathrm{HT}<0.9$ & $\begin{array}{l}\text { There are companies on the market with dominant } \\
\text { position }\end{array}$ \\
\hline $0.9 \leq \mathrm{HT} \leq 1$ & Monopoly \\
\hline
\end{tabular}

5) Linda index (L).

Calculation of the Lynde Index:

$$
L=\frac{1}{K(K-1)} * \sum_{i=1}^{k} Q_{i}
$$

Where $\mathrm{K}$ is the number of large sellers (from 2 to $\mathrm{N}$ ); $\mathrm{i}$ is the number of leading sellers among K large sellers.

$$
Q_{i}=\frac{A_{i}}{i} \div \frac{A_{k}-A_{i}}{K-i}
$$

$\mathrm{Ai}$; - total market share attributable to i sellers; Ak - market share attributable to $\mathrm{K}$ large sellers, 
The Lind index is calculated for $\mathrm{K}=2, \mathrm{~K}=3$ and so on until $\mathrm{Lk}+1$ is $>\mathrm{Lk}$, i.e. the first discontinuity, the L index, is obtained.

The Lind index determines the degree of inequality between the leading enterprises in the market and is used to determine the boundary of oligopoly.

Using these indices, let us analyze the competitive environment in the Russian oil market in the period 2015-2019.

First of all, let us find out what were the indicators of oil production with gas condensate in the 7 largest oil companies of the Russian Federation during this period (Table 3).

Table 3. Oil production with gas condensate, million tons.

\begin{tabular}{|c|c|c|c|c|c|c|c|c|}
\hline$\stackrel{\dot{\Xi}}{\grave{\nu}}$ & 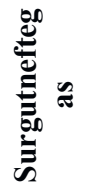 & 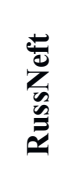 & 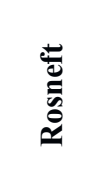 & 音 & $\begin{array}{l}\overline{\bar{a}} \\
\frac{\text { s }}{3}\end{array}$ & & $\begin{array}{l}\frac{1}{2} \\
\frac{2}{2} \\
2 \\
z\end{array}$ & 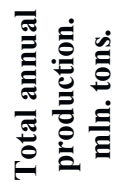 \\
\hline 2015 & 61.6 & 7.9 & 189.9 & 59.3 & 100.7 & 27.2 & 9.1 & 534.1 \\
\hline 2016 & 61.9 & 7.5 & 196.2 & 63.1 & 92 & 28.7 & 12.4 & 547.5 \\
\hline 2017 & 60.5 & 7.5 & 225.5 & 64.5 & 87.4 & 28.9 & 11.8 & 546.7 \\
\hline 2018 & 60.9 & 7.6 & 230.2 & 64.2 & 85.6 & 29.5 & 11.8 & 555.9 \\
\hline 2019 & 60.8 & 7.6 & 230.2 & 64.7 & 85.9 & 29.8 & 12.1 & 560.2 \\
\hline
\end{tabular}

As shown in Table 3, the volume of oil production with gas condensate increased by $4.9 \%$ from 2015 to 2019 .

The analysis of Table 4 shows that in 2015 the aggregate market share of oil occupied by our selected companies was $85,32 \%$. In 2016 , this figure decreased by 0,97 p.p. and reached $84,35 \%$. In 2017 and 2018 , the aggregate oil market share held by the companies was $88,92 \%$ and $88,11 \%$, respectively. As for the aggregate oil market share occupied by companies in 2019 , this figure decreased by 0,5 p.p. compared to the previous year and reached $87,67 \%$. For each year, the market share of each of the 7 companies under consideration was determined. In accordance with the values of the market share indicator, each company for all 5 years received a certain rank, which is required for calculation of the Hall-Teidman index. For example, Rosneft had the first rank for all five years, Lukoil had the second, Tatneft had the fifth, NOVATEK had the sixth, and RussNeft had the seventh. In 2015, Surgutneftegaz had the third rank, while Gazprom Neft had the fourth, and then in 2016-2019, Gazprom Neft had the third rank, while Surgutneftegaz had the fourth (Table 4).

Table 4. Market shares of Russian oil companies in 2015-2019.

\begin{tabular}{|c|c|c|c|c|c|c|c|c|c|c|}
\hline $\begin{array}{c}\text { Oil } \\
\text { companies }\end{array}$ & $\stackrel{n}{2}$ & $\underset{\simeq}{\stackrel{\sqrt[n]{0}}{0}}$ & 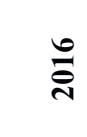 & 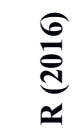 & $\frac{\pi}{2}$ & $\underset{\simeq}{\stackrel{ }{\mathcal{C}}}$ & $\stackrel{\infty}{\stackrel{\sim}{N}}$ & 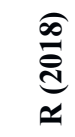 & 월 & $\begin{array}{l}\underset{\widetilde{d}}{\tilde{d}} \\
\widetilde{a}\end{array}$ \\
\hline Surgutneftegaz & 11.53 & 3 & 11.31 & 4 & 11.07 & 4 & 10.96 & 4 & 10.85 & 4 \\
\hline RussNeft & 1.48 & 7 & 1.37 & 7 & 1.37 & 7 & 1.37 & 7 & 1.36 & 7 \\
\hline Rosneft & 35.56 & 1 & 35.84 & 1 & 41.25 & 1 & 41.41 & 1 & 41.09 & 1 \\
\hline Gazprom Neft & 11.10 & 4 & 11.53 & 3 & 11.80 & 3 & 11.55 & 3 & 11.55 & 3 \\
\hline Lukoil & 18.85 & 2 & 16.80 & 2 & 15.99 & 2 & 15.40 & 2 & 15.33 & 2 \\
\hline Tatneft & 5.09 & 5 & 5.24 & 5 & 5.29 & 5 & 5.31 & 5 & 5.32 & 5 \\
\hline NOVATEK & 1.70 & 6 & 2.26 & 6 & 2.16 & 6 & 2.12 & 6 & 2.16 & 6 \\
\hline Amount & 85.32 & - & 84.35 & - & 88.92 & - & 88.11 & - & 87.67 & - \\
\hline
\end{tabular}


By calculating the Herfindahl-Hirschman Index (HHI). we can conclude that in 20152016 the oil market is a moderately concentrated market because $1000<\mathrm{HHI}<2000$. and in 2017-2019. - A highly concentrated market because $2000<\mathrm{HHI}<10000$. The CR-3 and CR4 market concentration indices support the 2015-2019 oil market conclusions of the Herfindahl-Hirschman Index (HHI). The Hall-Teidman Index (HT) was 0.34 in 2015. 2016. and 2019. and 0.33 in 2017 and 2018. - 0.33. This means that between 2015 and 2019. the oil market was a monopolistic competition market (Table 5).

Table 5. Results of calculations of market concentration indices CR-3. CR-4. Herfindahl-Hirschman index (HHI). Hall-Teidman index (HT).

\begin{tabular}{|c|c|c|c|c|c|}
\hline Indexes & $\mathbf{2 0 1 5}$ & $\mathbf{2 0 1 6}$ & $\mathbf{2 0 1 7}$ & $\mathbf{2 0 1 8}$ & $\mathbf{2 0 1 9}$ \\
\hline CR-3 & 65.94 & 64.16 & 69.03 & 68.36 & 67.98 \\
\hline CR-4 & 77.05 & 75.47 & 80.10 & 79.31 & 78.83 \\
\hline HHI & 1906.96 & 1861.69 & 2253.08 & 2239.86 & 2209.70 \\
\hline HT & 0.34 & 0.34 & 0.33 & 0.33 & 0.34 \\
\hline
\end{tabular}

Lind index (L). calculated for each year of the period under consideration. showed that during all 5 years 4 of 7 companies under consideration (Rosneft. Lukoil. Gazprom Neft. Surgutneftegaz) had a significant impact on the oil market (Table 6 - Table 10).

Table 6. Calculation of the Lind index for the Russian oil market in 2015.

\begin{tabular}{|c|c|c|c|c|c|c|c|c|}
\hline $\mathbf{k}$ & i & $\mathbf{Q}$ & $\mathbf{A i}$ & $\mathbf{A k}$ & k-i & Ak-Ai & k-1 & $\mathbf{L}$ \\
\hline 2 & 1 & 1.89 & 35.56 & 54.41 & 1 & 18.85 & 1 & 0.943 \\
\hline 3 & 1 & 2.34 & 35.56 & 65.94 & 2 & 30.39 & \multirow[t]{2}{*}{2} & \multirow[t]{2}{*}{0.783} \\
\hline 3 & 2 & 2.36 & 54.41 & 65.94 & 1 & 11.53 & & \\
\hline 4 & 1 & 2.57 & 35.56 & 77.05 & 3 & 41.49 & \multirow{3}{*}{3} & \multirow{3}{*}{0.580} \\
\hline 4 & 2 & 2.40 & 54.41 & 77.05 & 2 & 22.64 & & \\
\hline 4 & 3 & 1.98 & 65.94 & 77.05 & 1 & 11.10 & & \\
\hline 5 & 1 & 3.05 & 35.56 & 82.14 & 4 & 46.58 & \multirow{4}{*}{4} & \multirow{4}{*}{0.625} \\
\hline 5 & 2 & 2.94 & 54.41 & 82.14 & 3 & 27.73 & & \\
\hline 5 & 3 & 2.71 & 65.94 & 82.14 & 2 & 16.20 & & \\
\hline 5 & 4 & 3.78 & 77.05 & 82.14 & 1 & 5.09 & & \\
\hline
\end{tabular}

Table 7. Calculation of the Lind index for the Russian oil market in 2016.

\begin{tabular}{|c|c|c|c|c|c|c|c|c|}
\hline $\mathbf{k}$ & $\mathbf{i}$ & $\mathbf{Q}$ & $\mathbf{A i}$ & $\mathbf{A k}$ & k-i & $\mathbf{A k}-\mathbf{A} \mathbf{i}$ & k-1 & $\mathbf{L}$ \\
\hline 2 & 1 & 2.13 & 35.84 & 52.64 & 1 & 16.80 & 1 & 1.066 \\
\hline 3 & 1 & 2.53 & 35.84 & 64.16 & 2 & 28.33 & \multirow[t]{2}{*}{2} & \multirow[t]{2}{*}{0.802} \\
\hline 3 & 2 & 2.28 & 52.64 & 64.16 & 1 & 11.53 & & \\
\hline 4 & 1 & 2.71 & 35.84 & 75.47 & 3 & 39.63 & \multirow{3}{*}{3} & \multirow{3}{*}{0.576} \\
\hline 4 & 2 & 2.31 & 52.64 & 75.47 & 2 & 22.83 & & \\
\hline 4 & 3 & 1.89 & 64.16 & 75.47 & 1 & 11.31 & & \\
\hline 5 & 1 & 3.19 & 35.84 & 80.71 & 4 & 44.88 & \multirow{4}{*}{4} & \multirow{4}{*}{0.610} \\
\hline 5 & 2 & 2.81 & 52.64 & 80.71 & 3 & 28.07 & & \\
\hline 5 & 3 & 2.58 & 64.16 & 80.71 & 2 & 16.55 & & \\
\hline 5 & 4 & 3.60 & 75.47 & 80.71 & 1 & 5.24 & & \\
\hline
\end{tabular}

Table 8. Calculation of the Lynde index for the Russian oil market in 2017.

\begin{tabular}{|c|c|c|c|c|c|c|c|c|}
\hline $\mathbf{k}$ & $\mathbf{i}$ & $\mathbf{Q}$ & $\mathbf{A i}$ & $\mathbf{A k}$ & $\mathbf{k}-\mathbf{i}$ & $\mathbf{A k}-\mathbf{A i}$ & $\mathbf{k}-\mathbf{1}$ & $\mathbf{L}$ \\
\hline 2 & 1 & 2.58 & 41.25 & 57.23 & 1 & 15.99 & 1 & 1.290 \\
\hline 3 & 1 & 2.97 & 41.25 & 69.03 & 2 & 27.78 & 2 & 0.899 \\
\hline 3 & 2 & 2.43 & 57.23 & 69.03 & 1 & 11.80 & & \\
\hline 4 & 1 & 3.19 & 41.25 & 80.10 & 3 & 38.85 & \multirow{2}{*}{3} & \multirow{2}{*}{0.647} \\
\cline { 1 - 6 } 4 & 2 & 2.50 & 57.23 & 80.10 & 2 & 22.86 & & \\
\hline 4 & 3 & 2.08 & 69.03 & 80.10 & 1 & 11.07 & & \\
\hline
\end{tabular}




\begin{tabular}{|c|c|c|c|c|c|c|c|c|}
\hline 5 & 1 & 3.74 & 41.25 & 85.39 & 4 & 44.14 & \multirow{4}{*}{4} & \multirow{4}{*}{0.670} \\
\hline 5 & 2 & 3.05 & 57.23 & 85.39 & 3 & 28.15 & & \\
\hline 5 & 3 & 2.81 & 69.03 & 85.39 & 2 & 16.35 & & \\
\hline 5 & 4 & 3.79 & 80.10 & 85.39 & 1 & 5.29 & & \\
\hline
\end{tabular}

Table 9. Calculation of the Lind index for the Russian oil market in 2018.

\begin{tabular}{|c|c|c|c|c|c|c|c|c|}
\hline $\mathbf{k}$ & $\mathbf{i}$ & $\mathbf{Q}$ & $\mathbf{A} \mathbf{i}$ & $\mathbf{A k}$ & $\mathbf{k}-\mathbf{i}$ & $\mathbf{A k}-\mathbf{A i}$ & k-1 & $\mathbf{L}$ \\
\hline 2 & 1 & 2.69 & 41.41 & 56.81 & 1 & 15.40 & 1 & 1.345 \\
\hline 3 & 1 & 3.07 & 41.41 & 68.36 & 2 & 26.95 & \multirow[t]{2}{*}{2} & \multirow[t]{2}{*}{0.922} \\
\hline 3 & 2 & 2.46 & 56.81 & 68.36 & 1 & 11.55 & & \\
\hline 4 & 1 & 3.28 & 41.41 & 79.31 & 3 & 37.90 & \multirow{3}{*}{3} & \multirow{3}{*}{0.657} \\
\hline 4 & 2 & 2.52 & 56.81 & 79.31 & 2 & 22.50 & & \\
\hline 4 & 3 & 2.08 & 68.36 & 79.31 & 1 & 10.96 & & \\
\hline 5 & 1 & 3.83 & 41.41 & 84.62 & 4 & 43.21 & \multirow{4}{*}{4} & \multirow{4}{*}{0.672} \\
\hline 5 & 2 & 3.06 & 56.81 & 84.62 & 3 & 27.81 & & \\
\hline 5 & 3 & 2.80 & 68.36 & 84.62 & 2 & 16.26 & & \\
\hline 5 & 4 & 3.74 & 79.31 & 84.62 & 1 & 5.31 & & \\
\hline
\end{tabular}

Table 10. Calculation of the Lind index for the Russian oil market in 2019.

\begin{tabular}{|c|c|c|c|c|c|c|c|c|}
\hline $\mathbf{k}$ & i & $\mathbf{Q}$ & $\mathbf{A} \mathbf{i}$ & $\mathbf{A k}$ & k-i & Ak-Ai & k-1 & $\mathbf{L}$ \\
\hline 2 & 1 & 2.68 & 41.09 & 56.43 & 1 & 15.33 & 1 & 1.340 \\
\hline 3 & 1 & 3.06 & 41.09 & 67.98 & 2 & 26.88 & \multirow[t]{2}{*}{2} & \multirow[t]{2}{*}{0.917} \\
\hline 3 & 2 & 2.44 & 56.43 & 67.98 & 1 & 11.55 & & \\
\hline 4 & 1 & 3.27 & 41.09 & 78.83 & 3 & 37.74 & \multirow{3}{*}{3} & \multirow{3}{*}{0.656} \\
\hline 4 & 2 & 2.52 & 56.43 & 78.83 & 2 & 22.40 & & \\
\hline 4 & 3 & 2.09 & 67.98 & 78.83 & 1 & 10.85 & & \\
\hline 5 & 1 & 3.82 & 41.09 & 84.15 & 4 & 43.06 & \multirow{4}{*}{4} & \multirow{4}{*}{0.669} \\
\hline 5 & 2 & 3.05 & 56.43 & 84.15 & 3 & 27.72 & & \\
\hline 5 & 3 & 2.80 & 67.98 & 84.15 & 2 & 16.17 & & \\
\hline 5 & 4 & 3.70 & 78.83 & 84.15 & 1 & 5.32 & & \\
\hline
\end{tabular}

Thus, we considered the features of the competitive environment analysis of the industry market with the help of market concentration indices CR-3, CR-4, HerfindahlHirschman index, Hall-Teidman index, Lind index. Having analyzed the competitive environment of the Russian oil market in 2015-2019, it was possible to find out that the Russian oil market in 2015-2016 was moderately concentrated, in 2017-2019 - highly concentrated; during the whole period under consideration the Russian oil market was a monopolistic competition market, 4 of 7 companies under consideration (Rosneft, Lukoil, Gazprom Neft, Surgutneftegas) had a significant influence. In the period 2015-2019, the Russian oil market was not dominated by any of the companies in question. In 2018, the closest to the mark of more than $50 \%$ of the oil market share was Rosneft. Its share was equal to $41,41 \%$.

\section{Results}

In addition to analyzing the competitive environment in the oil market of Russia, it is important to analyze the impact of integration processes in this market on indicators of socio-economic development of the country. The indicators of integration processes will be: the number of mergers and acquisitions (X1), the total industry volume of mergers and acquisitions (X2), the total volume of all mergers and acquisitions (X3), the industry volume of all domestic transactions (X4). The indicators of socio-economic development of the country include gross domestic product (GDP) (R1), economic growth (R2), 
consolidated budget revenue (R3), foreign trade balance (R4), oil and gas condensate production (R5).

A specialized computer program Statistics was used for the correlation and regression analysis.

The analysis was conducted for the period from 2001 to 2019 inclusive.

During the analysis, we selected significant factors (explanatory variables; indicators of integration processes - X) for each indicator of socio-economic development of the country (explanatory variable - Y). For this purpose we checked the level of multi-collaboration between the explanatory variables and tested the explanatory variables by p-value criterion (criterion of significance level of explanatory variables); we calculated coefficient of determination, which allowed to determine the strength of influence of each of the selected explanatory variables on the explanatory variable in question; we constructed regression equation for each Y.

1) Consider the indicator U1 of GDP (Table 11).

Table 11. Analysis of multicollinearity of explanatory variables on GDP (Y1).

\begin{tabular}{|c|c|c|c|c|c|}
\hline \multirow{2}{*}{ Variable } & \multicolumn{5}{|c|}{ Correlations(Y1 GDP1) } \\
\cline { 2 - 6 } & $\mathbf{X 1}$ & $\mathbf{X 2}$ & $\mathbf{X 3}$ & $\mathbf{X 4}$ & Y1 \\
\hline $\mathrm{X} 1$ & 1.000000 & 0.434488 & 0.768959 & 0.488894 & 0.544881 \\
\hline $\mathrm{X} 2$ & 0.434488 & 1.000000 & 0.777854 & 0.910353 & 0.225030 \\
\hline $\mathrm{X3}$ & 0.768959 & 0.777854 & 1.000000 & 0.732845 & 0.593151 \\
\hline $\mathrm{X} 4$ & 0.488894 & 0.910353 & 0.732845 & 1.000000 & 0.084158 \\
\hline $\mathrm{Y} 1$ & 0.544881 & 0.225030 & 0.593151 & 0.084158 & 1.000000 \\
\hline
\end{tabular}

When analyzing the multicollinearity of the explanatory variables $(\mathrm{X})$, it was found that $\mathrm{X} 1$ and $\mathrm{X} 3$ were multicollinear $(0,77$; greater than or equal to 0,7 - strong multicollinearity of the explanatory variables). It was necessary to decide which of these two factors should be excluded (Table 12).

Table 12. Analysis of multicollinearity of explanatory variables by GDP (Y1).

\begin{tabular}{|c|c|c|c|c|c|c|}
\hline \multirow[t]{2}{*}{$N=19$} & \multicolumn{6}{|c|}{$\begin{array}{c}\text { Regression Summary for Dependent Variable: Y1 Real GDP. trln. rub. } \\
R=.79232786 R ?=.62778344 \text { Adjusted } R ?=.52143585 \\
F(4.14)=5.9031 p<.00534 \text { Std. Error of estimate: } 1.8336\end{array}$} \\
\hline & b * & $\begin{array}{c}\text { Std. Err of } \\
b^{*}\end{array}$ & b & $\begin{array}{c}\text { Std. Err of } \\
\text { b }\end{array}$ & $t(15)$ & p-value \\
\hline Intercept & & & 8.586619 & 1.382348 & 6.21162 & 0.000023 \\
\hline $\mathrm{X} 1$ & 0.153304 & 0.290554 & 0.000877 & 0.001663 & 0.52763 & 0.606020 \\
\hline $\mathrm{X} 2$ & 0.262439 & 0.480931 & 0.000004 & 0.000007 & 0.54569 & 0.583868 \\
\hline $\mathrm{X} 3$ & 0.949291 & 0.404978 & 0.000007 & 0.000003 & 2.34406 & 0.034360 \\
\hline $\mathrm{X} 4$ & -0.925387 & 0.411796 & -0.000014 & 0.000006 & -2.24720 & 0.041271 \\
\hline
\end{tabular}

According to the multicollinearity coefficient $b^{*}$ we excluded factor X1 - the number of M\&A deals (in this case the explanatory variable that has a smaller value of $b^{*}$ is excluded) (Table 13). 
Table 13. Test of explanatory variables by the p-value criterion (criterion of the level of significance of explanatory variables) on GDP (Y1).

\begin{tabular}{|c|c|c|c|c|c|c|}
\hline \multirow[t]{2}{*}{$N=19$} & \multicolumn{6}{|c|}{$\begin{array}{c}\text { Regression Summary for Dependent Variable: Y1 Real GDP. trln. rub } \\
R=.78764325 R ?=.62038189 \text { Adjusted } R ?=.54445827 \\
F(3.15)=8.1711 p<.00185 \text { Std. Error of estimate: } 1.7889\end{array}$} \\
\hline & b * & $\begin{array}{c}\text { Std. Err } \\
\text { off } \mathbf{b}^{*}\end{array}$ & b & $\begin{array}{c}\text { Std. Err } \\
\text { off b }\end{array}$ & $t(15)$ & p-value \\
\hline intercept & & & 9.019910 & 1.084906 & 8.31400 & 0.000001 \\
\hline X2 & 0.147250 & 0.418090 & 0.000002 & 0.000006 & 0.35220 & 0.729591 \\
\hline $\mathrm{X} 3$ & 1.112835 & 0.254291 & 0.000008 & 0.000002 & 4.37622 & 0.000542 \\
\hline $\mathrm{X} 4$ & -0.865426 & 0.386167 & -0.000013 & 0.000006 & -2.24107 & 0.040578 \\
\hline
\end{tabular}

By the p-value criterion (level of significance), we excluded the X2 factor - the total industry volume of (M\&A) mergers and acquisitions deals . In this case, we exclude those explanatory variables that do not meet the p-value criterion, that is, greater than 0.05 . Explanatory variables are excluded sequentially, i.e. first those $X^{\prime}$ s with p-value greater than other variables are excluded. Then the remaining explanatory variables that do not meet the p-value criterion are excluded in descending order by the same principle (Table 14).

Table 14. Results of correlation and regression analysis of the impact of integration processes in the oil market on GDP (Y1).

\begin{tabular}{|c|c|c|c|c|c|c|}
\hline \multirow[t]{2}{*}{$N=19$} & \multicolumn{6}{|c|}{$\begin{array}{c}\text { Regression Summary for Dependent Variable: Y1 Real GDP. trln. rub } \\
R=.78564792 R ?=.61724265 \text { Adjusted } R ?=.56939798 \\
F(2.16)=12.901 p<.00046 \text { Std. Error of estimate: } 1.7393\end{array}$} \\
\hline & b * & $\begin{array}{c}\text { Std. Err } \\
\text { of } b^{*}\end{array}$ & b & $\begin{array}{c}\text { Std. Err of } \\
b\end{array}$ & $t(15)$ & p-value \\
\hline intercept & & & 9.085083 & 1.039334 & 8.74126 & 0.000000 \\
\hline $\mathrm{X3}$ & 1.148048 & 0.227321 & 0.000008 & 0.000006 & 0.3 .5220 & 0.000118 \\
\hline $\mathrm{X} 4$ & -0.757182 & 0.227321 & -0.000011 & 0.000003 & -3.33089 & 0.004234 \\
\hline
\end{tabular}

The following results were obtained.

The coefficient of determination $\mathrm{R}^{\wedge} 2=0,62\left(0,6<=\mathrm{R}^{\wedge} 2<0,7\right)$, that is, in this model moderately strong relationship, factors X3 - total volume of all mergers and acquisitions and X4 - industry volume of all domestic transactions moderately strong impact on Y1 GDP. Sixty-two percent of the changes in Y1 are due to the effects of X3 and X4.

The regression equation is as follows:

$\mathrm{Y}=9,085083+0,000008 \times \mathrm{X} 3-0,000011 \times \mathrm{X} 4$.

Thus, the total volume of all mergers and acquisitions and the industry volume of all domestic transactions have a moderately large impact on GDP.

2) Consider Y2 economic growth (Table 15).

Table 15. Multicollinearity analysis of explanatory variables on economic growth (Y2).

\begin{tabular}{|c|c|c|c|c|c|}
\hline \multirow{2}{*}{ Variable } & \multicolumn{5}{|c|}{ Correlations (Y2 Economic growth) } \\
\cline { 2 - 6 } & $\mathbf{X 1}$ & $\mathbf{X 2}$ & $\mathbf{X 3}$ & $\mathbf{X 4}$ & Y2 \\
\hline $\mathrm{X} 1$ & 1.000000 & 0.434488 & 0.768959 & 0.488894 & 0.039812 \\
\hline $\mathbf{X 2}$ & 0.434488 & 1.000000 & 0.777854 & 0.910353 & -0.191246 \\
\hline $\mathrm{X} 3$ & 0.768959 & 0.777854 & 1.000000 & 0.732845 & -0.085515 \\
\hline $\mathrm{X} 4$ & 0.488894 & 0.910353 & 0.732845 & 1.000000 & -0.070494 \\
\hline $\mathrm{Y} 2$ & 0.039812 & -0.191246 & -0.085515 & -0.070494 & 1.000000 \\
\hline
\end{tabular}


When analyzing the multicollinearity of the explanatory variables $(\mathrm{X})$, it was found that the indicators X1 and X3 were multicollinear. It was necessary to decide which of these two factors should be excluded (Table 16).

Table 16. Analysis of multicollinearity of explanatory variables on economic growth (Y2).

\begin{tabular}{|c|c|c|c|c|c|c|}
\hline \multirow[t]{2}{*}{$N=19$} & \multicolumn{6}{|c|}{$\begin{array}{c}\text { Regression Summary for Dependent Variable: Y2 Economic growth } \\
R=.32545238 \mathrm{R} ?=.10591925 \text { Adjusted } R ?=--- \\
F(4.14)=.41464 p<.79532 \text { Std. Error of estimate: } .04229\end{array}$} \\
\hline & b * & $\begin{array}{c}\text { Std. Err of } \\
b^{*}\end{array}$ & b & $\begin{array}{l}\text { Std. Err of } \\
b\end{array}$ & $t(15)$ & p-value \\
\hline intercept & & & 1.043657 & 0.031880 & 32.73731 & 0.000000 \\
\hline $\mathrm{X} 1$ & 0.047351 & 0.450316 & 0.000004 & 0.000038 & 0.10515 & 0.917748 \\
\hline $\mathrm{X} 2$ & -0.786172 & 0.745373 & -0.000000 & 0.000000 & -1.05474 & 0.309409 \\
\hline X3 & 0.072871 & 0.627657 & 0.000000 & 0.000000 & 0.11610 & 0.909223 \\
\hline $\mathrm{X} 4$ & 0.568647 & 0.638223 & 0.000000 & 0.000000 & 0.89099 & 0.387993 \\
\hline
\end{tabular}

According to the multicollinearity coefficient $b^{*}$ we excluded the factor X1 - the number of M\&A deals (Table 17).

Table 17. Test of explanatory variables by p-value criterion (criterion of significance level of explanatory variables) on economic growth (Y2).

\begin{tabular}{|c|c|c|c|c|c|c|}
\hline \multirow[t]{2}{*}{$N=19$} & \multicolumn{6}{|c|}{$\begin{array}{c}\text { Regression Summary for Dependent Variable: Y2 Economic growth } \\
R=.32436576 R ?=.10521315 \text { Adjusted } R ?=--- \\
F(3.15)=.58792 p<.63225 \text { Std. Error of estimate: } .04087\end{array}$} \\
\hline & b * & $\begin{array}{c}\text { Std. Err of } \\
b^{*}\end{array}$ & b & $\begin{array}{c}\text { Std. Err of } \\
b\end{array}$ & $t(15)$ & p-value \\
\hline intercept & & & 1.045649 & 0.024785 & 42.18910 & 0.000000 \\
\hline $\mathrm{X} 2$ & -0.821750 & 0.641883 & -0.000000 & 0.000000 & -1.28022 & 0.219913 \\
\hline $\mathrm{X} 3$ & 0.123384 & 0.390407 & 0.000000 & 0.000000 & 0.31604 & 0.756328 \\
\hline $\mathrm{X} 4$ & 0.587168 & 0.592872 & 0.000000 & 0.000000 & 0.99038 & 0.337697 \\
\hline
\end{tabular}

According to the p-value criterion, we saw that all three of the remaining factors do not meet its condition at this stage, so we began to sequentially exclude them depending on the value of $p$-value in descending order.

The first factor that was excluded was factor X3 - the total volume of all mergers and acquisitions (Table 18).

Table 18. Test of explanatory variables by the $p$-value criterion (criterion of the level of significance of explanatory variables) on economic growth (Y2).

\begin{tabular}{|c|c|c|c|c|c|c|}
\hline \multirow[t]{2}{*}{$\mathbf{N}=19$} & \multicolumn{6}{|c|}{$\begin{array}{c}\text { Regression Summary for Dependent Variable: Y2 Economic growth } \\
R=.31504766 \mathrm{R} ?=.09925503 \text { Adjusted } R ?=-- \\
F(2.16)=.88154 p<.43333 \text { Std. Error of estimate: } .03970\end{array}$} \\
\hline & b * & $\begin{array}{c}\text { Std. Err of } \\
b^{*}\end{array}$ & b & $\begin{array}{l}\text { Std. Err of } \\
b\end{array}$ & $t(15)$ & p-value \\
\hline intercept & & & 1.0051278 & 0.016742 & 62.79348 & 0.000000 \\
\hline $\mathrm{X} 2$ & -0.741991 & 0.573346 & -0.000000 & 0.000000 & -1.29414 & 0.213985 \\
\hline $\mathrm{X4}$ & 0.604979 & 0.573346 & 0.000000 & 0.000000 & 1.05517 & 0.307020 \\
\hline
\end{tabular}

Then we excluded the factor X4 - the industry volume of all domestic transactions (Table 19). 
Table 19. Test of explanatory variables by p-value criterion (criterion of significance level of explanatory variables) on economic growth (Y2).

\begin{tabular}{|c|c|c|c|c|c|c|}
\hline \multirow{3}{*}{$\mathbf{N}=19$} & \multicolumn{5}{|c|}{$\begin{array}{r}\text { Regression Summary for Dependent Variable: Y2 Economic growth } \\
\mathbf{R}=\mathbf{. 1 9 1 2 4 5 8 4} \mathbf{R} \mathbf{=}=\mathbf{. 0 3 6 5 7 4 9 7} \text { Adjusted R?=-- }\end{array}$} \\
\cline { 2 - 7 } & $\mathbf{F}(\mathbf{1 . 1 7}=\mathbf{6 4 5 3 8} \mathbf{p}<\mathbf{4 3 2 8 6}$ Std. Error of estimate: .03983 \\
\hline b * & $\begin{array}{c}\text { Std. Err } \\
\text { of } \mathbf{b}^{*}\end{array}$ & $\mathbf{b}$ & $\begin{array}{c}\text { Std. Err } \\
\text { of b }\end{array}$ & $\mathbf{t}(\mathbf{1 5})$ & p-value \\
\hline intercept & & & 1.043163 & 0.014920 & 69.91634 & 0.000000 \\
\hline $\mathbf{X 2}$ & -0.191246 & 0.238059 & -0.000000 & 0.000000 & -0.80335 & 0.432859 \\
\hline
\end{tabular}

The following results were obtained.

Determination coefficient $\mathrm{R}^{\wedge} 2=0,036575\left(\mathrm{R}^{\wedge} 2<0.4\right)$, that is, there is no strong relationship in this model. By default, we can conclude that the selected X2 - total industry M\&A (mergers and acquisitions) has no significant effect on Y2 - economic growth.

It is not possible to construct a regression equation using this model. All of the factors considered do not significantly affect the change in economic growth.

3) Let us consider the indicator Y3 - revenues of the consolidated budget of the Russian Federation (Table 20).

Table 20. Analysis of multicollinearity of explanatory variables for consolidated budget revenues (Y3).

\begin{tabular}{|c|c|c|c|c|c|}
\hline \multirow{2}{*}{ Variable } & \multicolumn{5}{|c|}{ Correlations (Y3 Budget revenues 1) } \\
\cline { 2 - 6 } & $\mathbf{X 1}$ & $\mathbf{X 2}$ & $\mathbf{X 3}$ & $\mathbf{X 4}$ & Y3 \\
\hline $\mathrm{X} 1$ & 1.000000 & 0.434488 & 0.768959 & 0.488894 & 0.574300 \\
\hline $\mathrm{X} 2$ & 0.434488 & 1.000000 & 0.777854 & 0.910353 & 0.205222 \\
\hline $\mathrm{X} 3$ & 0.768959 & 0.777854 & 1.000000 & 0.732845 & 0.619723 \\
\hline $\mathrm{X} 4$ & 0.488894 & 0.910353 & 0.732845 & 1.000000 & 0.110325 \\
\hline $\mathrm{Y} 3$ & 0.574300 & 0.205222 & 0.619723 & 0.110325 & 1.000000 \\
\hline
\end{tabular}

When analyzing the multicollinearity of the explanatory variables $(\mathrm{X})$, it was found that the indicators X1 and X3 were multicollinear. It was necessary to decide which of these two factors should be excluded (Table 21).

Table 21. Analysis of multicollinearity of explanatory variables on consolidated budget revenues (Y3).

\begin{tabular}{|c|c|c|c|c|c|c|}
\hline \multirow[t]{2}{*}{$\mathrm{N}=19$} & \multicolumn{6}{|c|}{$\begin{array}{c}\text { Regression Summary for Dependent Variable: Y3 Real income from the } \\
\text { consolidated budget } \\
\mathrm{R}=.80330664 \mathrm{R} ?=\mathbf{6 4 5 3 0 1 5 6} \text { Adjusted } \mathrm{R} ?=. \mathbf{5 4 3 9 5 9 1 4} \\
\mathrm{F}(\mathbf{4 . 1 4})=\mathbf{6 . 3 6 7 5} \mathrm{p}<. \mathbf{0 0 3 9 0} \text { Std. Error of estimate: } \mathbf{. 6 8 3 7 1}\end{array}$} \\
\hline & b * & $\begin{array}{c}\text { Std. Err } \\
\text { of } b^{*}\end{array}$ & b & $\begin{array}{c}\text { Std. Err of } \\
b\end{array}$ & $t(15)$ & p-value \\
\hline intercept & & & 2.909459 & 0.515453 & 5.64447 & 0.000061 \\
\hline X1 & 0.076952 & 0.283634 & 0.000168 & 0.000620 & 0.27131 & 0.790114 \\
\hline $\mathrm{X} 2$ & -0.108480 & 0.469478 & -0.000001 & 0.000002 & -0.23107 & 0.820606 \\
\hline X3 & 1.121702 & 0.395333 & 0.000003 & 0.000001 & 2.83736 & 0.013174 \\
\hline $\mathrm{X} 4$ & -0.650575 & 0.401989 & -0.000004 & 0.000002 & -1.61839 & 0.127879 \\
\hline
\end{tabular}

According to the multicollinearity coefficient $b^{*}$ we excluded the factor X1 - the number of $\mathrm{M} \& \mathrm{~A}$ (mergers and acquisitions) deals (Table 22). 
Table 22. Test of explanatory variables by p-value criterion (criterion of significance level of explanatory variables) on consolidated budget revenues (Y3).

\begin{tabular}{|c|c|c|c|c|c|c|}
\hline \multirow[t]{2}{*}{$N=19$} & \multicolumn{6}{|c|}{$\begin{array}{c}\text { Regression Summary for Dependent Variable: Y3 Real income from the } \\
\text { consolidated budget } \\
\mathbf{R}=\mathbf{8 0 2 1 4 5 0 3} \mathrm{R} ?=\mathbf{6 4 3 4 3 6 6 6} \text { Adjusted } \mathrm{R} ?=. \mathbf{5 7 2 1 2 3 9 9} \\
\mathrm{F}(3.15)=\mathbf{9 . 0 2 2 8} \mathrm{p}<. \mathbf{0 0 1 1 7} \text { Std. Error of estimate: } .66226\end{array}$} \\
\hline & b * & $\begin{array}{c}\text { Std. Err } \\
\text { of } b^{*}\end{array}$ & b & $\begin{array}{c}\text { Std. Err } \\
\text { of } b\end{array}$ & $t(15)$ & p-value \\
\hline intercept & & & 2.992537 & 0.401631 & 7.45096 & 0.000002 \\
\hline $\mathrm{X} 2$ & -0.166301 & 0.405195 & -0.000001 & 0.000002 & -0.41042 & 0.687300 \\
\hline $\mathrm{X} 3$ & 1.203794 & 0.246449 & 0.000003 & 0.000001 & 4.88456 & 0.000198 \\
\hline $\mathrm{X} 4$ & -0.620477 & 0.374257 & -0.000004 & 0.000002 & -1.65789 & 0.118100 \\
\hline
\end{tabular}

According to the p-value criterion, we saw that factors $\mathrm{X} 2$ and $\mathrm{X} 4$ do not satisfy its condition at this stage, so we began to sequentially exclude them depending on the value of p-value in descending order.

The first factor that was excluded was factor X2 - total industry M\&A (mergers and acquisitions) volume (Table 23)

Table 23. Results of the correlation and regression analysis of the impact of integration processes in the oil market on consolidated budget revenues (Y3).

\begin{tabular}{|c|c|c|c|c|c|c|}
\hline \multirow[t]{2}{*}{$\mathrm{N}=19$} & \multicolumn{6}{|c|}{$\begin{array}{c}\text { Regression Summary for Dependent Variable: Y3 Real income from the } \\
\text { consolidated budget } \\
\mathrm{R}=.77389704 \mathrm{R} ?=\mathbf{5 9 8 9 1 6 6 3} \text { Adjusted } \mathrm{R} ?=\mathbf{. 5 4 8 7 8 1 2 1} \\
\mathrm{F}(\mathbf{2 . 1 6 )}=\mathbf{1 1 . 9 4 6} \mathrm{p}<. \mathbf{0 0 0 6 7} \text { Std. Error of estimate: } \mathbf{. 6 8 0 0 8}\end{array}$} \\
\hline & b * & $\begin{array}{c}\text { Std. Err of } \\
b^{*}\end{array}$ & b & $\begin{array}{c}\text { Std. Err } \\
\text { of } b\end{array}$ & $t(15)$ & p-value \\
\hline intercept & & & 3.152736 & 0.383561 & 8.21964 & 0.000000 \\
\hline X3 & 1.226805 & 0.254137 & 0.000003 & 0.000001 & 4.82733 & 0.000186 \\
\hline X4 & -0.838142 & 0.254137 & -0.000005 & 0.000002 & -3.29799 & 0.004538 \\
\hline
\end{tabular}

After excluding the factor X2, it turned out that X4 satisfies the condition of the p-value criterion.

The following results were obtained.

The coefficient of determination $\mathrm{R}^{\wedge} 2=0,6\left(0,6<=\mathrm{R}^{\wedge} 2<0,7\right)$, that is, in this model is moderately strong relationship, factors X3 - total volume of all M\&A (mergers and acquisitions) deals and $\mathrm{X} 4$ - industry volume of all domestic deals moderately strong impact on Y3 - consolidated budget revenues. In $60 \%$ of the cases, changes in Y3 are caused by the impact of X3 and X4.

The regression equation has the following form:

$\mathrm{Y}=3,1527+0,000003 \times \mathrm{X} 3-0,000005 \times \mathrm{X} 4$.

Thus, the total volume of all mergers and acquisitions and the industry volume of all domestic transactions have a moderately strong impact on the revenues of the consolidated budget of the Russian Federation.

4) Consider the Y4 indicator of the foreign trade balance (Table 24). 
Table 24. Analysis of multicollinearity of explanatory variables on foreign trade balance (Y4).

\begin{tabular}{|c|c|c|c|c|c|}
\hline \multirow{2}{*}{ Variable } & \multicolumn{5}{|c|}{ Correlations(Y4 Trade balance1) } \\
\cline { 2 - 6 } & $\mathbf{X 1}$ & $\mathbf{X 2}$ & $\mathbf{X 3}$ & $\mathbf{X 4}$ & Y4 \\
\hline $\mathrm{X} 1$ & 1.000000 & 0.434488 & 0.768959 & 0.488894 & -0.004979 \\
\hline $\mathrm{X} 2$ & 0.434488 & 1.000000 & 0.777854 & 0.910353 & -0.148147 \\
\hline $\mathbf{X} 3$ & 0.768959 & 0.777854 & 1.000000 & 0.732845 & -0.188422 \\
\hline $\mathrm{X} 4$ & 0.488894 & 0.910353 & 0.732845 & 1.000000 & -0.060253 \\
\hline $\mathrm{Y} 4$ & -0.004979 & -0.148147 & -0.188422 & -0.060253 & 1.000000 \\
\hline
\end{tabular}

When analyzing the multicollinearity of the explanatory variables $(\mathrm{X})$, it was found that the indicators X1 and X3 were multicollinear. It was necessary to decide which of these two factors should be discarded (Table 25).

Table 25. Analysis of multicollinearity of explanatory variables on foreign trade balance (Y4).

\begin{tabular}{|c|c|c|c|c|c|c|}
\hline \multirow[t]{2}{*}{$N=19$} & \multicolumn{6}{|c|}{$\begin{array}{c}\text { Regression Summary for Dependent Variable: Y4 Balance of trade } \\
R=.33120011 \mathrm{R} ?=.10969352 \text { Adjusted } R ?=- \\
F(4.14)=43123 p<.78383 \text { Std. Error of estimate: } .2651 \mathrm{E} 2\end{array}$} \\
\hline & b * & $\begin{array}{c}\text { Std. Err } \\
\text { of } b^{*}\end{array}$ & b & $\begin{array}{c}\text { Std. Err } \\
\text { of } b\end{array}$ & $t(15)$ & p-value \\
\hline intercept & & & 1740426 & 199873.5 & 8.707639 & 0.000001 \\
\hline $\mathrm{X} 1$ & 0.343822 & 0.449365 & 184 & 240.4 & 0.765128 & 0.456900 \\
\hline $\mathrm{X} 2$ & -0.147755 & 0.743798 & 0 & 1.0 & -0.198650 & 0.845393 \\
\hline $\mathbf{X 3}$ & -0.581302 & 0.626331 & 0 & 0.4 & -0.928107 & 0.369078 \\
\hline X4 & -332168 & 0.636875 & 0 & 0.9 & 0.521560 & 0.610129 \\
\hline
\end{tabular}

According to the multicollinearity coefficient $b^{*}$, we discarded the factor X3 - the total volume of all M\&A (mergers and acquisitions) deals (Table 26).

Table 26. Test of explanatory variables by $p$-value criterion (criterion of significance level of explanatory variables) on foreign trade balance (Y4).

\begin{tabular}{|c|c|c|c|c|c|c|}
\hline \multirow[t]{2}{*}{$\mathrm{N}=19$} & \multicolumn{6}{|c|}{$\begin{array}{c}\text { Regression Summary for Dependent Variable: } Y 4 \text { Balance of trade }(\mathrm{R}= \\
.23434019 \mathrm{R} ?=.05491532 \text { Adjusted } \mathrm{R} ?=-- \\
\mathrm{F}(3.15)=.29053 \mathrm{p}<.83156 \text { Std. Error of estimate: } 2639 \mathrm{E} 2\end{array}$} \\
\hline & $\mathbf{b} *$ & $\begin{array}{c}\text { Std. Err } \\
\text { off } b^{*}\end{array}$ & b & $\begin{array}{c}\text { Std. Err } \\
\text { off b }\end{array}$ & $t(15)$ & p-value \\
\hline intercept & & & 1755751 & 198267.8 & 8.855449 & 0.000000 \\
\hline X1 & 0.024616 & 0.287865 & 13 & 154.0 & 0.085511 & 0.932986 \\
\hline $\mathrm{X} 2$ & -0.543247 & 0.606809 & -1 & 0.8 & -0.895252 & 0.384794 \\
\hline $\mathrm{X} 4$ & 0.422259 & 0.626519 & 1 & 0.9 & 0.673976 & 0.510580 \\
\hline
\end{tabular}

According to the p-value criterion, we saw that all three of the remaining factors do not meet its condition at this stage, so we began to sequentially exclude them depending on the value of $\mathrm{p}$-value in descending order.

The first factor X1 was excluded - the number of mergers and acquisitions (Table 27). 
Table 27. Test of explanatory variables by the p-value criterion (criterion of the significance level of explanatory variables) on the foreign trade balance (Y4).

\begin{tabular}{|c|c|c|c|c|c|c|}
\hline \multirow[t]{2}{*}{$N=19$} & \multicolumn{6}{|c|}{$\begin{array}{l}\text { Regression Summary for Dependent Variable: Y4 Balance of trade } \\
R=.23335513 \mathrm{R} ?=.05445462 \text { Adjusted } R ?=-.-- \\
\mathrm{F}(2.16)=.46073 \mathrm{p}<\text {. Std. Error of estimate: } 2556 \mathrm{E} 2\end{array}$} \\
\hline & b * & $\begin{array}{c}\text { Std. Err } \\
\text { of } b^{*}\end{array}$ & b & $\begin{array}{c}\text { Std. Err } \\
\text { of } b\end{array}$ & $t(15)$ & p-value \\
\hline Intercept & & & 1769783 & 107771.1 & 16.42168 & 0.000000 \\
\hline $\mathrm{X} 2$ & -0.544767 & 0.587431 & -1 & 0.8 & -0.92737 & 0.367512 \\
\hline $\mathrm{X} 4$ & 0.435677 & 0.587431 & 1 & 0.8 & 0.74167 & 0.469038 \\
\hline
\end{tabular}

Then we excluded the factor X4 - the industry volume of all domestic transactions (Table 28).

Table 28. Test of explanatory variables by p-value criterion (criterion of significance level of explanatory variables) on foreign trade balance (Y4).

\begin{tabular}{|c|c|c|c|c|c|c|}
\hline \multirow{3}{*}{$\mathbf{N}=19$} & \multicolumn{5}{|c|}{$\begin{array}{r}\text { Regression Summary for Dependent Variable: Y4 Balance of Trade } \\
\mathbf{R}=\mathbf{. 2 3 4 3 4 0 1 9} \text { R?= .05491532 Adjusted R?= =-- }\end{array}$} \\
\cline { 2 - 7 } & $\mathbf{b}^{*}$ & $\begin{array}{c}\text { Std. Err of } \\
\mathbf{b}^{*}\end{array}$ & $\mathbf{b}$ & $\begin{array}{c}\text { Std. Err of } \\
\text { b }\end{array}$ & $\mathbf{t}(\mathbf{1 5 )}$ & p-value \\
\hline $\begin{array}{c}\text { interce } \\
\text { pt }\end{array}$ & & & 1733063 & 94450.54 & 18.34890 & 0.000000 \\
\hline $\mathbf{X 2}$ & -0.148147 & 0.239859 & 0 & 0.31 & -0.61764 & 0.544998 \\
\hline
\end{tabular}

The following results were obtained.

Determination coefficient $\mathrm{R}^{\wedge} 2=0,02195\left(\mathrm{R}^{\wedge} 2<0.4\right)$, that is, there is no strong relationship in this model. By default, we can conclude that the selected X2 - total industry M\&A has no significant effect on Y4 - foreign trade balance.

It is impossible to construct a regression equation using this model. All of the considered factors do not significantly affect the change in the balance of foreign trade.

5) Let us consider the indicator Y5 - production of oil with gas condensate (Table 29).

Table 29. Analysis of multicollinearity of explanatory variables for oil production with gas condensate (Y5).

\begin{tabular}{|c|c|c|c|c|c|}
\hline \multirow{2}{*}{ Variable } & \multicolumn{5}{|c|}{ Correlations (Y5 Oil Production 1) } \\
\cline { 2 - 6 } & $\mathbf{X 1}$ & $\mathbf{X 2}$ & $\mathbf{X 3}$ & $\mathbf{X 4}$ & Y4 \\
\hline $\mathrm{X} 1$ & 1.000000 & 0.434488 & 0.768959 & 0.488894 & 0.505128 \\
\hline $\mathrm{X} 2$ & 0.434488 & 1.000000 & 0.777854 & 0.910353 & 0.207993 \\
\hline $\mathbf{X 3}$ & 0.768959 & 0.777854 & 1.000000 & 0.732845 & 0.518634 \\
\hline $\mathrm{X} 4$ & 0.488894 & 0.910353 & 0.732845 & 1.000000 & 0.044169 \\
\hline $\mathrm{Y} 5$ & 0.505128 & 0.207993 & 0.518634 & 0.044169 & 1.000000 \\
\hline
\end{tabular}

When analyzing the multicollinearity of the explanatory variables $(\mathrm{X})$, it was found that the indicators X1 and X3 were multicollinear. It was necessary to decide which of these two factors should be excluded (Table 30). 
Table 30. Analysis of multicollinearity of explanatory variables for oil production with gas condensate (Y5).

\begin{tabular}{|c|c|c|c|c|c|c|}
\hline \multirow[t]{2}{*}{$\mathrm{N}=19$} & \multicolumn{6}{|c|}{$\begin{array}{c}\text { Regression Summary for Dependent Variable: Y5 Oil production with gas } \\
\text { condensate } R=.74649193 R ?=.55725020 \text { Adjusted } R ?=43075026 \\
F(4.14)=4.4051 p<.01634 \text { Std. Error of estimate: } 43.567\end{array}$} \\
\hline & b* & $\begin{array}{c}\text { Std. Err of } \\
b^{*}\end{array}$ & b & $\begin{array}{c}\text { Std. Err } \\
\text { of } b\end{array}$ & $\mathbf{t}(15)$ & p-value \\
\hline intercept & & & 378.7522 & 32.84531 & 11.53139 & 0.000000 \\
\hline $\mathrm{X} 1$ & 0.28851 & 0.316890 & 0.0360 & 0.03950 & 0.91045 & 0.377996 \\
\hline $\mathrm{X} 2$ & 0.57248 & 0.524523 & 0.0002 & 0.00016 & 1.09144 & 0.293509 \\
\hline $\mathrm{X} 3$ & 0.65754 & 0.441685 & 0.0001 & 0.00007 & 1.48872 & 0.158740 \\
\hline $\mathrm{X} 4$ & -1.09992 & 0.449121 & -0.0004 & 0.00015 & -2.4490 & 0.028095 \\
\hline
\end{tabular}

According to the multicollinearity coefficient $b^{*}$, we discarded factor X1 - the number of M\&A(mergers and acquisitions) deals (Table 31).

Table 31. P-value test of explanatory variables (criterion of significance level of explanatory variables) for oil production with gas condensate (Y5).

\begin{tabular}{|c|c|c|c|c|c|c|}
\hline \multirow[t]{2}{*}{$N=19$} & \multicolumn{6}{|c|}{$\begin{array}{l}\text { Regression Summary for Dependent Variable: } Y 5 \text { Oil production with gas } \\
\text { condensate } R=.72872203 R ?=.53103579 \text { Adjusted } R ?=43724295 \\
F(3.15)=5.6618 p<.00847 \text { Std. Error of estimate: } 43.317\end{array}$} \\
\hline & b * & $\begin{array}{l}\text { Std. Err } \\
\text { of } b^{*}\end{array}$ & b & $\begin{array}{l}\text { Std. Err } \\
\text { of } b\end{array}$ & $t(15)$ & p-value \\
\hline intercept & & & 396.5171 & 26.27019 & 15.09380 & 0.000000 \\
\hline $\mathrm{X} 2$ & 0.355701 & 0.464693 & 0.0001 & 0.00014 & 0.76546 & 0.455877 \\
\hline $\mathrm{X} 3$ & 0.965325 & 0.282636 & 0.0001 & 0.00004 & 3.41543 & 0.003834 \\
\hline $\mathrm{X} 4$ & -0.987087 & 0.429211 & -0.0003 & 0.00014 & -2.29975 & 0.036242 \\
\hline
\end{tabular}

For the p-value criterion, we excluded the factor X2 - total industry M\&A(mergers and acquisitions) volume. The remaining factors satisfy the $\mathrm{p}$-value criterion (Table 32).

Table 32. Results of correlation and regression analysis of the impact of integration processes in the oil market on oil production with gas condensate (Y5).

\begin{tabular}{|c|c|c|c|c|c|c|}
\hline \multirow[t]{2}{*}{$N=19$} & \multicolumn{6}{|c|}{$\begin{array}{c}\text { Regression Summary for Dependent Variable: Y5 Oil production with gas } \\
\text { condensate } \\
R=.71604286 R ?=.51271738 \text { Adjusted } R ?=.45180705 \\
F(2.16)=8.4176 p<.00318 \text { Std. Error of estimate: } 42.753 \\
\end{array}$} \\
\hline & b * & $\begin{array}{c}\begin{array}{c}\text { Std. Err of } \\
b^{*}\end{array} \\
\end{array}$ & b & $\begin{array}{c}\text { Std. Err of } \\
\text { b }\end{array}$ & $t(15)$ & p-value \\
\hline intercept & & & 399.9470 & 25.54808 & 15.65468 & 0.000000 \\
\hline X3 & 1.050387 & 0.256489 & 0.0002 & 0.00004 & 4.09525 & 0.000845 \\
\hline $\mathrm{X} 4$ & -0.725602 & 0.256489 & -0.0002 & 0.00008 & -2.82898 & 0.012096 \\
\hline
\end{tabular}

The following results were obtained.

Determination coefficient $\mathrm{R}^{\wedge} 2=0,51\left(0,3<\mathrm{R}^{\wedge} 2<0,6\right)$, that is, in this model a moderate relationship, factors X3 - total volume of all M\&A deals and X4 - industry volume of all domestic deals moderately strongly affect U5 - oil production with gas condensate. In 51\% of cases, changes in U5 are due to the impact of X3 and X4.

The regression equation is as follows:

$$
\mathrm{Y}=399,9470+0,0002 \times \mathrm{X} 3-0,0002 \times \mathrm{X} 4
$$

So, the total volume of all mergers and acquisitions and the industry volume of all domestic deals are moderately strongly influenced by gas condensate oil production. 
Thus, a correlation and regression analysis of the impact of integration processes in the oil market on the indicators of socio-economic development of the country was conducted. GDP and consolidated budget revenues are moderately strongly affected by the integration processes in the oil market. On the volume of oil production with gas condensate - a moderate impact. At the same time, integration processes at the oil market do not have a significant impact on economic growth and foreign trade balance.

\section{Discussion}

Currently, oil and gas complex is a determinant in the economic development of any state. Oil and gas are used in almost all sectors of the economy, providing the distribution of economic benefits and being the basis of marketable products. Oil and gas are and will be an important source of energy in the near future. A special impact on the world market of oil and gas products, its structure, the degree of liberalization, pricing had a global financial crisis caused by the impact of the COVID-19 pandemic [27, 28].

The basic principles of pricing in oil production are:

- the Brent crude oil benchmark is recognized as a nominal value. Brent oil is an indicator of quality and at the same time an object of economic relations.

- the pricing system established in the country depends on changes in Brent prices;

- the price fixed in the sales contracts is determined by the following principle: a premium in American dollars is added or subtracted to the price of Brent oil. In this case the difference is determined with the help of oil quality indicators.

The price of oil depends on the dynamics of Brent prices and on the ratio of the value of Brent to those oil grades that are produced in a certain territory.

In modern conditions there is a tendency of increasing consumption of oil in the countries that have developed production and in the countries that do not have their own resources.

It should also be noted that pricing in the oil industry is influenced by the competition between the key oil sellers.

Competition in the market encouraged a shift from long-term contracts to short-term contracts. So the long term contract contained information on oil grade, conveyance volume, price, and different discounts and mark ups to illustrate changes in certain circumstances. Oil prices are affected by following factors. and the characteristics of personalized refining capability change in the seasonal and regional demand, and the magnitude of transportation costs.

The emergence of commodity exchanges influenced the emergence of new forms of oil trading. These may include wholesale trading, short-term contracts, trading in secondary derivatives.

Oil industry services are traded on the New York Trade Exchange, the London International Petroleum Exchange, and the Singapore Trade Exchange.

Oil pricing is influenced by a combination of factors.

The factors that influence the decline in oil prices are subdivided, depending on the time, into long-term and short-term.

The short-term decline in oil prices is due to:

- seasonal decline in demand;

- a short-term decline in economic growth;

- speculative play of oil traders;

- inconsistency in the actions of oil exporters;

- political pressure exerted by major crude oil importers and consumers;

- destabilization of the political and economic situation in the importing countries.

The long-term decline in oil prices is due to: 
- implementation of energy and resource saving technologies, rational energy consumption;

- increase in the share of alternative energy sources in the fuel and energy resources structure;

- introduction of modern oil production, refining, transportation and use technologies;

- increasing the efficiency of special geological and other activities to find, discover and prepare oil deposits for commercial development;

- increasing the share of low-cost oil in the fuel and energy balance.

Short-term increases in oil prices can be caused by the following factors:

- economic and political instability in countries that are major oil exporters;

- oil stock reduction in the countries that are the main consumers of oil;

- natural and man-made disasters that destroy oil production, refining and transportation structure;

- the maximum possible volume of oil production in the exporting countries;

- inflationary processes in the countries that are major oil consumers;

- seasonal increase in demand for petroleum products;

- high level of utilization of the primary refining capacities in the countries that are major oil importers.

The long-term increase in oil prices is caused by the following factors:

- worsening conditions associated with the development of oil fields;

- an increase in the distance between oil production sites and the sites of its main refining and consumption;

- increase in prices for the products of the industries related to oil extraction (metallurgy, machine-building, transportation, services and intermediary services);

- the prices of petroleum products in major oil-consuming countries are rising;

- increased energy consumption related to technological development;

- the number of people living on the earth has increased.

The price of natural gas is affected by the following factors:

- the impact of oil and other fuel prices. the relationship between the prices of natural gas and other fuels is determined through reference prices and sliding price section;

- supply and demand. natural gas is bought and sold at a short-term fixed price. This means that when signing a long-term contract and determining the monthly natural gas price, a special index will be used;

- two-way monopoly. this principle means that the big seller and the big buyer in the course of bilateral negotiations determine the price, usually for one year:

- the cost of gas is substituted for the cost of competitive energy sources, adjusted for the cost of transportation from the border;

- the price is determined by the authorized state body at the level of production cost. in this case, the price includes coverage of the «cost of services», including investments and the rate of return;

- the price is determined by the authorized state body below the cost price. At the same time, the price of gas is set below the average cost of production and transportation costs, compensating the difference with government subsidies to the population.

Let's consider the dynamics of the price of Urals oil. Urals is a Russian high-grain export oil blend (Fig. 4). The grade is produced from oil produced in Khanty-Mansiysk Autonomous District, Yamalo-Nenets Autonomous District, Tatarstan, Bashkortostan and Samara Region. The main producers are «Rosneft», «Lukoil», «Gazprom Neft», «Surgutneftegaz», «Tatneft», and «Bashneft». Historically its price is determined on the basis of quotations of the North Sea Brent - with a discount from one to several US dollars per «barrel». 


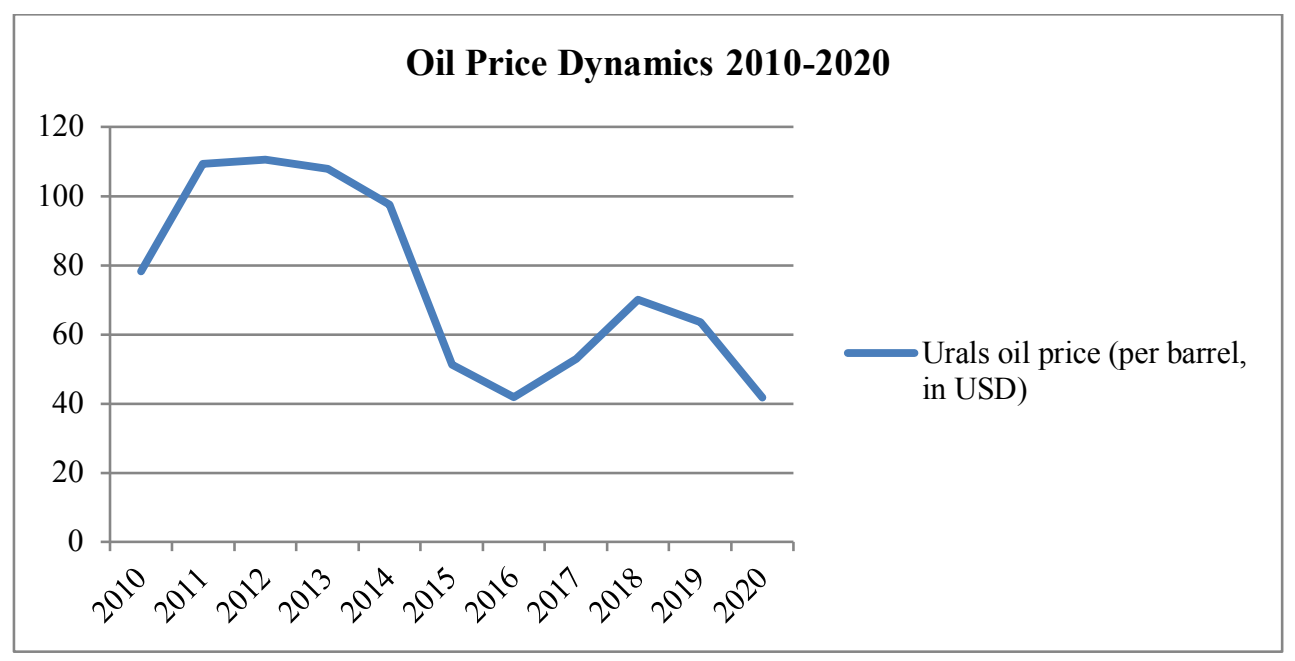

Fig. 4. Price dynamics for Urals oil 2010-2020.

The presented Ural oil price dynamic chart clearly proves the cyclical nature of the global economy. Therefore, from 2010 to 2012, the price of oil rose by US\$32,32, and between 2013 and 2019, the price fluctuated, but overall, relative to 2012, the price fell by 1.7 times to US\$63,59. In 2020, the price will drop by USD 21,76.

Oil prices affect the development of economic and political processes. This indicator is the key to determining the following:

- stock prices of oil and gas companies;

- inflation levels in oil importing countries;

- the overall level of energy prices;

- the strength of concentrating and concentralization of production;

- the strength of research and development activities.

\section{Conclusions}

Thus, the results of the Russian oil and gas complex have a significant impact on the economic development of the country, so it is important to organize and implement an effective and competent state management in this industry; regularly analyze the competitive environment of the oil market; conduct a correlation and regression analysis of the impact of integration processes in the oil and gas complex on socio-economic indicators; study and analyze factors affecting pricing; establish the dynamics of oil prices

The national regulations of the oil and gas complex should contribute to the growth of the country's socio-economic indicators, the improvement of the population's living standards and quality of life, and the improvement of Russia's investment attraction. However, its scale may vary at different stages of the country's socio-economic development, depending on specific circumstances, including geopolitical nature.

The analysis of the competitive environment of the oil market is carried out with the help of market concentration indices CR-3, CR-4, Herfindahl-Hirschman index, HallTeidman index, Lind index. Having analyzed the competitive environment of the Russian oil market in 2015-2019, it was possible to find out that the Russian oil market in 20152016 was moderately concentrated, in 2017-2019 - highly concentrated; during the whole period under consideration the Russian oil market was a monopolistic competition market, 4 of 7 companies under consideration («Rosneft», «Lukoil», «Gazprom Neft», «Surgutneftegas») had a significant influence. 
As a result of the correlation and regression analysis of the impact of integration processes in the oil market on the indicators of socio-economic development of the country in the period 2001-2019, it was found that. on GDP, consolidated budget revenues integration processes in the oil market had a moderately strong impact. On the volume of oil production with gas condensate - a moderate impact. At the same time integration processes on the oil market had no significant impact on economic growth and foreign trade balance.

\section{References}

1. W. Liu, A. Ramirez, Renewable and Sustainable Energy Reviews 76, 628-644 (2017) https://doi.org/10.1016/j.rser.2017.03.087

2. G. Klychova, A. Zakirova, E. Sadrieva et al, E3S Web of Conferences 91, 06002 (2019) doi.org/10.1051/e3sconf/20199106002

3. R. Khalfaoui, S. Sarwar, A.K. Tiwari, Resources Policy 62, 22-32 (2019) https://doi.org/10.1016/j.resourpol.2019.03.004

4. W. Jiang, Y. Liu, The North American Journal of Economics and Finance 56, 101357 (2021) https://doi.org/10.1016/j.najef.2020.101357

5. M. Schimmel, W. Liu, E. Worrell, Earth-Science Reviews 194, 455-471 (2019) https://doi.org/10.1016/j.earscirev.2019.03.006

6. O. Esen, S.C. Özer, A. Soylu et al, International Journal of Coal Geology 231, 103602 (2020) https://doi.org/10.1016/j.coal.2020.103602

7. J. Leontieva, E. Zaugarova, G. Klychova et al, MATEC Web of Conferences 170, 01087 (2018) doi.org/10.1051/matecconf/201817001087

8. L.H. Ederington, Ch.S. Fernando, Th.K. Lee et al, Energy Economics 94, 105079 (2021) https://doi.org/10.1016/j.eneco.2020.105079

9. R.O. Alao, C. Payaslioglu, Resources Policy 70, 101957 (2021) https://doi.org/10.1016/j.resourpol.2020.101957

10. P. Castillo, C. Montoro, V. Tuesta, Journal of Macroeconomics 66, 103259 (2020) https://doi.org/10.1016/j.jmacro.2020.103259

11. A. Talipova, S.G. Parsegov, P. Tukpetov, Energy Policy 135, 111012 (2019) https://doi.org/10.1016/j.enpol.2019.111012

12. G. Klychova, A. Zakirova, R. Mannapova, et al, E3S Web of Conferences 110, 02075 (2019) doi.org/10.1051/e3sconf/201911002075

13. C.J. Axon, R.C. Darton, Sustainable Production and Consumption 15 (2021) https://doi.org/10.1016/j.spc.2021.01.018

14. M. Karatayev, S. Hall, Resources Policy 68, $101746 \quad$ (2020) https://doi.org/10.1016/j.resourpol.2020.101746

15. M. Rajavuori, K. Huhta, Energy Policy 144, $111646 \quad$ (2020) https://doi.org/10.1016/j.enpol.2020.111646

16. M.S. Rahman, F. Khan, A. Shaikh et al, Ocean Engineering 174, 125-134 (2019) https://doi.org/10.1016/j.oceaneng.2019.01.037

17. Ch.S. Tang, L.P. Veelenturf, Transportation Research Part E: Logistics and Transportation Review 129, 1-11 (2019) https://doi.org/10.1016/j.tre.2019.06.004

18. A. Klychova, G. Klychova, A. Zakirova, et al, E3S Web of Conferences 110, 02072 (2019) doi.org/10.1051/e3sconf/201911002072 
19. F. Liu, Sh. Shao, Ch. Zhang, Energy Economics 92, 104979 (2020) https://doi.org/10.1016/j.eneco.2020.104979

20. F. Alamgir, S.B. Amin, Energy Reports 7, 693-703 (2021) https://doi.org/10.1016/j.egyr.2021.01.027

21. B. Lin, R. Bai, Research in International Business and Finance 56, 101357 (2021) https://doi.org/10.1016/j.ribaf.2020.101357

22. I.D. Raheem, A.K. Bello, Y.H. Agboola, Resources Policy 68, 101804 (2020) https://doi.org/10.1016/j.resourpol.2020.101804

23. C.-Zh. Yao, Ch. Liu, W.-J. Ju, Physica A: Statistical Mechanics and its Applications 550, 124096 (2020) https://doi.org/10.1016/j.physa.2019.124096

24. A.K. Tiwari, N. Trabelsi, F. Alqahtanie, Sh. Hammoudeh, Energy Economics 83, 445466 (2019) https://doi.org/10.1016/j.eneco.2019.07.014

25. M. Raghavan, Energy Economics 86, 104633 https://doi.org/10.1016/j.eneco.2019.104633

26. S. Sarwar, A.K. Tiwari, C. Tingqiu, Resources Policy 66, 101608 (2020) https://doi.org/10.1016/j.resourpol.2020.101608

27. X. Zhuang, Y. Wei, B. Zhang, Physica A: Statistical Mechanics and its Applications 399, 113-125 (2014) https://doi.org/10.1016/j.physa.2013.12.048

28. B.B. Ahundjanov, Sh.B. Akhundjanov, B.B. Okhunjanov, Journal of Economics and Business.

Available

online

4 ,

105979

(2021)

https://doi.org/10.1016/j.jeconbus.2020.105979 